\title{
Correction to: Putting the French Duty of Vigilance Law in Context: Towards Corporate Accountability for Human Rights Violations in the Global South?
}

\author{
Almut Schilling-Vacaflor ${ }^{1}$
}

Published online: 4 March 2022

(C) The Author(s) 2022

\section{Correction to: Human Rights Review (2021) 22:109-127 https://doi.org/10.1007/s12142-020-00607-9}

This article was intended for inclusion in the Special Issue on Business and Human Rights Regulation After the UN Guiding Principles. It was, however, published in a separate issue, Volume 22, Issue 1, 2021 and is available at https://doi.org/10.1007/ s12142-020-00607-9.

Open Access This article is licensed under a Creative Commons Attribution 4.0 International License, which permits use, sharing, adaptation, distribution and reproduction in any medium or format, as long as you give appropriate credit to the original author(s) and the source, provide a link to the Creative Commons licence, and indicate if changes were made. The images or other third party material in this article are included in the article's Creative Commons licence, unless indicated otherwise in a credit line to the material. If material is not included in the article's Creative Commons licence and your intended use is not permitted by statutory regulation or exceeds the permitted use, you will need to obtain permission directly from the copyright holder. To view a copy of this licence, visit http://creativecommons.org/licen ses/by/4.0/.

Publisher's Note Springer Nature remains neutral with regard to jurisdictional claims in published maps and institutional affiliations.

The original article can be found online at https://doi.org/10.1007/s12142-020-00607-9.

Almut Schilling-Vacaflor

1 Institute of Social Sciences, Osnabrück University, Seminarstr. 33, 49074 Osnabrück, Germany 